\title{
Determinants of Dysmenorrhea Pain Levels of in Adolescents
}

\author{
Dwi Wahyu Wulan Sulistyowati ${ }^{1 \text { (corresponding author) }}$, Ani Media Harumi ${ }^{2}$ \\ ${ }^{1}$ Department of Midwifery, Poltekkes Kemenkes Surabaya, Indonesia; dwwulan1@gmail.com \\ ${ }^{2}$ Department of Midwifery, Poltekkes Kemenkes Surabaya, Indonesia (amediaharumi@ gmail.com)
}

Submitted: December 27, 2018 -Revised: July 16, 2019 -Accepted: July 26, 2019 -Published: January 31, 2020

\begin{abstract}
Menstrual pain sometimes makes women unable to move normally so that quality deteriorates in their daily lives. Complaints that appear vary in intensity and are different for each person. Some women only feel mild pain, but others feel very severe pain, stomach like squeezing, vomiting, discomfort in the stomach, pain in the breast, even fever and headaches. The design of this study was cross-sectional. The population used in this study were all middle school and vocational high school students who experienced dysmenorrhea every time menstruation in the last 2 months period as many as 190 students and a sample of 130 female students. Sampling used was a simple random technique, namely the determination of samples taken randomly. The dependent variable was dysmenorrhea pain levels, while the independent variable were anxiety, activity, age, and nutritional status. The instrument used was a questionnaire and checklist. The analysis technique used was the multiple linear regression test. From the results of the study, there was a strong influence of anxiety, age, and nutritional status on the dysmenorrhea pain levels. Whereas there was no influence of activity on dysmenorrhea pain levels.
\end{abstract}

Keywords: dysmenorrhea; pain; anxiety; nutritional; activity; age

\section{INTRODUCTION}

Dysmenorrhea is pain during or immediately before menstruation being one of the most common gynecologic problems in women of all ages. ${ }^{(1,2,3)}$ Menstrual pain sometimes makes women unable to move normally so that quality deteriorates in their daily lives. Some women only feel mild pain, but others feel very severe pain, stomach like squeezing, vomiting, abdominal discomfort, pain in the breast, even fever and headache so that all complaints are experienced such efforts are made to be able to handle it. ${ }^{(4)}$

According to WHO data, the average incidence of dysmenorrhea in young women is between $16,8-81 \%$. While in Indonesia, it is estimated that $55 \%$ of productive age women have pain during menstruation. The incidence (prevalence) of menstrual pain ranges from $45-95 \%$ among productive age women. ${ }^{(5)}$ The incidence of primary type dysmenorrhea in Indonesia is around $54.89 \%$, while the rest are patients with secondary types. In East Java, the incidence of dysmenorrhea is $64.25 \%$ which consists of $54.89 \%$ of primary dysmenorrhea and $9.36 \%$ of secondary dysmenorrhea. ${ }^{(6)}$

Primary dysmenorrhoea occurs at 6-12 months after menarche, due to high levels of prostaglandin (PGs) released from secretory endometrium, causing painful uterine contractions. Secondary dysmenorrhea is menstrual pain caused by pathology in the pelvis or uterus, can occur at any time after menarche ${ }^{(2)}$. The onset of primary dysmenorrhea is certainly influenced by many factors. Some of the factors thought to play a role in the onset of primary dysmenorrhea include prostaglandin, a disorder of sex steroid hormones (disorders estrogen and progesterone balance), nervous system (neurological), vasopressin and psychic. However, research in recent years shows that increasing levels of prostaglandins and estrogens, especially estradiol, play an important role in the pathophysiology of primary dysmenorrhea. ${ }^{(7)}$

Nutritional status expresses the amount of intake of nutrients which is then converted into energy and energy reserves in the body. Phospholipids are synthesized into arachidonic acid, with the help of the enzyme cyclooxygenase-2, arachidonic acid forms prostaglandin F2 $\alpha$. Prostaglandin F2 $\alpha$ is the most important intermediary in the occurrence of primary dysmenorrhea. ${ }^{(5)}$ Age is a unit of time that measures the time of existence of an object or creature, both living and dead. For example, the age of a human being is said to be 15 years measured from the time she was born until the age was calculated. Therefore, age is measured from the time she was born until now. ${ }^{(7)}$ Seeing the phenomena that occur above, the authors are interested in examining the Determinants of Dysmenorrhea Pain in Teenagers. It is expected that from this study, adolescents who experience dysmenorrhea can control the level of pain that is felt, can even prevent the occurrence of dysmenorrhea by regulating their nutritional status in the normal category. 


\section{METHODS}

The design of the study was cross-sectional, with the type of analytical research that aims to analyze the determinants of the dysmenorrhea pain levels. The study was conducted from January to February 2017. The study was conducted to adolescent girls at junior high school who experienced dysmenorrhea in every menstrual cycle in 2 months. The population size were 190 female students. Samples were taken by simple random sampling technique and obtained the sample size of 130 female students. The instrument used in data collection process were questionnaire and checklist. Data processing was done namely editing, coding, scoring, entering data and tabulating. Data were analyzed using multiple linear regression test.

\section{RESULTS}

Respondents who experienced moderate-level pain of dysmenorrhea were almost half as many as $46 \%$, and there were still respondents who experienced severe pain levels of $22 \%$.

Table 1. The distribution of dysmenorrhea pain levels

\begin{tabular}{|c|c|c|}
\hline Pain levels & Frequency & Percentage \\
\hline Light & 42 & 32 \\
Moderate & 59 & 46 \\
Serious & 29 & 22 \\
\hline Total & 130 & 100 \\
\hline
\end{tabular}

Table 2. The results of multiple regression test

\begin{tabular}{|c|c|c|c|c|c|}
\hline \multicolumn{2}{|c|}{ Variable } & Frequency & Percentage & p-value & Information \\
\hline $\begin{array}{c}\text { Nutritional } \\
\text { status }\end{array}$ & $\begin{array}{c}\text { Thin } \\
\text { Normal } \\
\text { Overweight }\end{array}$ & $\begin{array}{c}30 \\
94 \\
6\end{array}$ & $\begin{array}{c}23 \\
72 \\
5\end{array}$ & 0.45 & Significant \\
\hline Age & $\begin{array}{l}\text { Early youth } \\
\text { Late youth }\end{array}$ & $\begin{array}{l}68 \\
62 \\
\end{array}$ & $\begin{array}{l}52 \\
48\end{array}$ & 0.021 & Significant \\
\hline Anxiety & $\begin{array}{l}\text { Normal } \\
\text { Light } \\
\text { Moderate } \\
\text { Serious }\end{array}$ & $\begin{array}{l}48 \\
17 \\
28 \\
37\end{array}$ & $\begin{array}{l}37 \\
13 \\
22 \\
28\end{array}$ & 0.000 & Significant \\
\hline Behavior & $\begin{array}{c}\text { Activity } \\
\text { No activity }\end{array}$ & $\begin{array}{l}81 \\
49\end{array}$ & $\begin{array}{l}62 \\
51\end{array}$ & 0.993 & Not significant \\
\hline
\end{tabular}

Respondents almost all had normal nutritional status, which was as much as $72 \%$. Half of the respondents in the Early Youth category were 52\%. Respondents who experienced Normal anxiety at the time of dysmenorrhea were $37 \%$, while still found severe anxiety as much as $28 \%$. The behavior of respondents at the time of experiencing dysmenorrhea mostly remained as much as $62 \%$. Partial test explains how far the influence of independent variables on the dependent variable. The partial test results showed that there was an influence between anxiety and BMI on the level of pain, with p-value of 0.0000 . While the influence of age on the level of pain obtained p-value of 0.021 . This means that there was a strong influence of anxiety, BMI and age on the pain levels. The partial test results explained that there was no effect of activity on the pain levels, with a pvalue of 0.993 .

\section{DISCUSSION}

The results showed that the age significantly affected the level of dysmenorrheal pain in adolescents. Menstrual pain often occurs in young women because it has not reached biological maturity (especially reproductive maturity, ie imperfect endometrial growth) and psychological. Increasing age of a woman, then the incidence of dysmenorrhea will diminish, Sufficient knowledge of the factors of dysmenorrhea will encourage women to make efforts to prevent pain so that the pain threshold can be controlled. The effort that can be done 
is to provide health education about Dismenorhea to early adolescents so that when these early teens experience Dismenorhea, the adolescent can adapt well. ${ }^{(3,6,8)}$

The results showed no significant influence of the nutritional status on the dysmenorrhea pain levels. On young women need to maintain a good nutritional status, by eating a balanced diet because it is in need during menstruation. During menstruation, the luteal phase will increase the nutritional requirements; and if this is ignored, the impact will be complaints that cause a feeling of discomfort during menstruation. The results of research conducted by Trimayasari state that students with low nutritional status have a 1.2 times greater risk of experiencing dysmenorrhea than students with normal nutritional status. Nutritional status refers to the nutritional intake that has been received by the body. Nutritional deficiencies in young women can disrupt the ovulation cycle, this can interfere with the occurrence of fertility disorders. Besides, lack of nutrition can also affect sexual maturation, growth, organ function and will be a cause of disruption of reproductive function. Disruption of reproductive function will appear with menstrual disorders that occur. ${ }^{(7,9)}$

Based on the results, there is an influence of anxiety on the dysmenorrhea pain levels in adolescents. The effect of the level of anxiety on the dysmenorrhea pain levels in adolescents in this study showed higher levels of anxiety, the higher incidence of dysmenorrhea in adolescents. Someone is said to be anxious when experiencing symptoms of anxiety about something uncertain, difficulty concentrating, anxiety, insomnia, pale and unable to be relaxed. ${ }^{(1)}$ The incidence of dysmenorrhea shows how often complaints of dysmenorrhea arise in young women as a symptom of STD, although sometimes dysmenorrhea is considered common in adolescents who experience menstruation.

The results of the study showed that there was no significant effect of the activity on the dysmenorrhea pain levels in adolescents. A woman who often experiences a series of episodes of pain without ever recovered in a long period, then fear will arise, and vice versa. As a result, clients will be better prepared to take the actions needed to relieve pain, for example by taking medicine, exercise, and so on. This is following the opinion Widyanata $^{(6)}$, which states that a person's experiences of pain before, does not reduce the people's fears in the face of pain to come.

\section{CONCLUSION}

It can be concluded that there was a strong influence of anxiety, age, and nutritional status on the dysmenorrhea pain levels. Whereas there was no influence of activity on dysmenorrhea pain levels.

As suggestion, the health professionals continue to provide counseling on reproductive health issues, especially girls and women, especially teenagers. Provide information and counseling materials so that they can add insight into the reproductive health of adolescents and women, especially regarding the determinants of dysmenorrhea pain level factors

\section{REFERENCES}

1. Cavaggioni G, Lia C, Resta S, Antonielli T, Benedetti Panici P, Megiorni F, Porpora MG. Are mood and anxiety disorders and alexithymia associated with endometriosis? A preliminary study. BioMed research international. 2014;2014.

2. Nasri M, Barati A, Ramezani A. The effects of aerobic training and pelvic floor muscle exercise on primary dysmenorrhea in adolescent girls. Journal of Clinical Nursing and Midwifery. 2017;5(3).

3. Seven M, Güvenç G, Akyüz A, Eski F. Evaluating dysmenorrhea in a sample of Turkish nursing students. Pain Management Nursing. 2014 Sep 1;15(3):664-71.

4. Saguni FC, Madianung A, Masi G. The relationship between dysmenorrhea with young women learning activities in Tomohon Christian High School (Hubungan dismenore dengan aktivitas belajar remaja putri di SMA Kristen I Tomohon). Jurnal Keperawatan. 2013;1(1).

5. Sari SE, Kartasurya MI, Pangestuti DR. Anemia and Mild Physical Activity are Risk Factors of Dysmenorrhea in Young Women (Anemia dan Aktivitas Fisik yang Ringan Mempengaruhi Faktor Risiko Dismenore pada Remaja Putri). Jurnal Kesehatan Masyarakat (e-Journal). 2018;6(5):437-44.

6. Widyanata KA, Putra IG, Daryaswanti PI, Febianingsih NP. Physical Activity and Meditation to Reduce Primary Dysmenorrhea In Adolescent. In8th International Nursing Conference on Education, Practice and Research Development in Nursing (INC 2017). Atlantis Press; 2017.

7. Trimayasari D, Kuswandi K. The relationship between the age of menarche and the nutritional status of grade 2 junior high school students with the incidence of dysmenorrhea (Hubungan usia menarche dan status gizi siswi SMP kelas 2 dengan kejadian dismenore). Jurnal Obstretika Scienta. 2015;2(2):195-216. 
8. Vincenzo De Sanctis M, Soliman A, Bernasconi S, Bianchin L, Bona G, Bozzola M, Buzi F, De C, Sanctis MD, Tonini G, Rigon10 F. Primary dysmenorrhea in adolescents: prevalence, impact and recent knowledge. Pediatric Endocrinology Reviews (PER). 2015;13(2):465-73.

9. Rahmadhayanti E, Rohmin A. The Relationship between Nutritional Status and Age of Menarche and Primary Dysmenorrhea in Adolescent Girls Class XI, SMA Negeri 15 Palembang (Hubungan Status Gizi dan Usia Menarche dengan Dismenorhea Primer pada Remaja Putri Kelas XI SMA Negeri 15 Palembang). Jurnal Kesehatan. 2016;7(2):255-9. 